Rumiati et al., 2019

Volume 5 Issue 2, pp. 833-847

Date of Publication: 01st October 2019

DOI-https://dx.doi.org/10.20319/pijss.2019.52.833847

This paper can be cited as: Rumiati, A. T., Gunawan, J., E Ekasari, N., (2019). Developing Indicators to Measure Sustainable Marine Tourism Development Study Case: In Selong Belanak Village, West Praya, Central Lombok Province. PEOPLE: International Journal of Social Sciences, 5(2), 833-847.

This work is licensed under the Creative Commons Attribution-Non Commercial 4.0 International License. To view a copy of this license, visit http://creativecommons.org/licenses/by-nc/4.0/ or send a letter to Creative Commons, PO Box 1866, Mountain View, CA 94042, USA.

\title{
DEVELOPING INDICATORS TO MEASURE SUSTAINABLE MARINE TOURISM DEVELOPMENT STUDY CASE: IN SELONG BELANAK VILLAGE, WEST PRAYA, CENTRAL LOMBOK PROVINCE
}

\author{
Agnes Tuti Rumiati \\ Department of Statistics, Institut Teknologi Sepuluh Nopember, Surabaya, Indonesia \\ agnestuti@yahoo.com \\ Janti Gunawan \\ Department of BusinessManagement, Institut Teknologi Sepuluh Nopember, Surabaya, \\ Indonesia \\ jantigunawan2010@gmail.com \\ Nazihah Ekasari \\ Department of Statistics, Institut Teknologi Sepuluh Nopember, Surabaya, Indonesia \\ naziaekasari@gmail.com

\begin{abstract}
Tourism has been selected as one of the strategic sectors to reach Indonesia sustainable development goals. Land, marine, cultural, and other type of tourism have been developed, but importantly, Indonesia tourism development has been driven mostly by government strategic decision, as it relates with infrastructure. Although Indonesia is a country with the third longest coasts in the world, however, the coastal tourism is less developed. Beside infrastructure, coastal tourism is more complex because it relates to access of both land and water, with more diverse community. The tourism management study stresses that development indicators are necessary to manage the process of shifting one economy, such as fishing or farming village, toward sustainable
\end{abstract}


tourism based economy. It requires the integration of policy, implementation, evaluation and community feedbacks. This study proposes indicators to measure coastal tourism in Indonesia, which covers 11 indicators that reflects the dimensions of sustainable tourism. Cluster analysis is used to group the indicators, and the indicator is developed and tested at Selong Belanak village, a costal tourism in Lombok, Indonesia.

\section{Keywords}

Coastal Tourism, Indicators, Sustainable Development

\section{Background}

Indonesia is one of the countries with the most tourist destination in the world, this is evidenced by the increase in the number of domestic and foreign tourist trips each year to Indonesia. The Ministry of Tourism, said that if the tourism sector is placed as the backbone of the nation's economy, Indonesia has many competitive advantages and competitive advantages. It is estimated that in 2019, the tourism industry will become the largest foreign exchange earner, as much as USD 24 billion, surpassing the oil and gas, coal, palm oil sector (Kementrian, 2016). With the condition of Indonesia which is an archipelagic country, of course the equitable development of tourism is homework for the government. Therefore, it is expected that every region in Indonesia can independently develop tourism with or without government assistance.

Lombok Island is one of the world-famous Indonesian islands, from the beauty of the beach to the waterfall, Lombok Island presents natural beauty and comfort for tourists during their visit. But unfortunately, in reality there are still many tourist areas on the island of Lombok that have not been exposed. Selong Belanak village in Central Lombok province is one of them, even though if it is observed more deeply, Selong Belanak village has many tourist destinations that can attract the attention of tourists, including the Selong Belanak beach which has a shape like a Crescent with white sand and extensive plantation land can be developed into natural tourism or education for tourists (Putra, 2017).

Therefore, it is necessary to arrange supporting infrastructure for the development of the tourism village of Selong Belanak. One solution is to use tourism development in Selong Belanak Village based on empowering communities with digital technology, so that people can use information technology as the main actor in managing tourism. To build the technology, indicators are needed as a measurement tool for tourism development, which focuses on the effect of tourism relations with the environment. 
In building indicators, it is necessary to integrate the general public into policy making to encourage public participation (Miller, 2001). According to Moldan, clear information from the public, should be in the form of clear indicators to be understood and clear (Moldan, 1997). Indicators play an important role in the second stage of the Rules of Indicator cycle. Based on the rules of the indicator, it can be further developed in accordance with the conditions of the local area as follows.

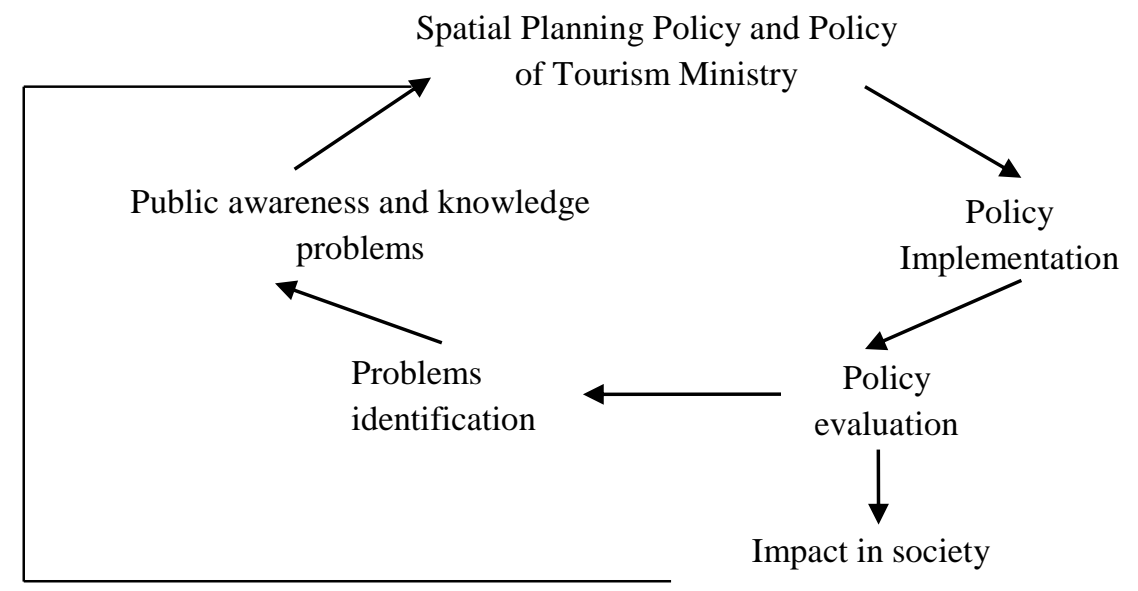

Figure 1: Indicator Rules According to Conditions

On the new indicator flow, an examination of the impacts that occur on the community after the implementation of the policy. So that, it can be used as an input for government to regulate existing tourism policies.

\section{Literature Review}

\subsection{Delphi Method}

The analytical method used is the Delphi method, the Delphi method itself is a process carried out in groups to survey and gather opinions from experts related to a particular topic. This method is useful for structuring the group communication process so that the process will run effectively, so that the group can solve the problem. This method is used when opinions and judgments from experts are needed but other factors such as time and / or distance make it difficult for the panel expert to sit together (Helmer, 1967).

The Delphi method by definition is a process in groups that involves interaction between researchers and a group of experts related to a particular topic; usually through the help of a questionnaire. This method is used to get consensus about projections / future trends using a systematic information gathering process. This method is useful when opinions and evaluations 
from experts and practitioners are needed in solving problems. This will be very useful when experts cannot be presented at the same time. According to Linstone and Turoff, the Delphi method can be applied in the following fields (Linstone \& Turrof, 2002).

a. Collect current and historical data that is not available and / or inaccurate.

b. Evaluating the possibility of budget allocation options.

c. Reviewing urban and regional planning options.

d. Planning a lecture curriculum.

e. Develop an educational model.

f. Map the pros and cons regarding policy choices.

g. Assess the priority of a choice

\subsection{Calculation of Score}

Calculation of the score uses the mean value of each question in one indicator. The score for each question is the value given by stakeholders consisting of five Likert scales. Assessment for each value on the likert scale is in accordance with sustainable tourism for development guidebook by UNWTO (World Tourism Organization (UNWTO), 2013). The explanation for each value scale is as follows

Table 1: Calculation of Score

\begin{tabular}{|c|l|c|}
\hline 1 & Region with special needs - Highest Priority for further intervention & $\begin{array}{c}\text { Priority for } \\
\text { intervention } \\
\text { High }\end{array}$ \\
\hline 2 & $\begin{array}{l}\text { In need for repair - also in consideration for further intervention / } \\
\text { support }\end{array}$ & $\begin{array}{c}\text { Low } \\
\text { Priority for } \\
\text { intervention }\end{array}$ \\
\hline 3 & $\begin{array}{l}\text { Possibly gaining advantage from reparation- but less needing of } \\
\text { intervention }\end{array}$ & \\
\hline 4 & Looks satisfying - maintain & Area with clear strength - used as model \\
\hline $\mathrm{X}$ & No information for answering question / Could not be valued & \\
\hline
\end{tabular}

Furthermore, from these scores, the mean values are calculated using the following formula:

$$
\bar{x}=\frac{\sum_{i=1}^{n} x_{i}}{n}
$$

Mean is a statistic that shows the middle between the values of the random variable that has been measured (Walpole, 1993). 


\section{Methodology}

\subsection{Study Location}

One of the villages that have coastal tourism potential is the village of Selong Belanak in Central Lombok province, West Nusa Tenggara-Indonesia. The beach in Selong Belanak Village has a shape like a Crescent with white sand and extensive plantation land that can be developed into natural tourism or education for tourists.

\subsection{Study Stages}

The method used to develop indicators of sustainable coastal tourism development is carried out through several stages as follows:

\section{1) Literature Review}

Literature review as the basis to develops concepts and variables. From the literature review a variety of indicators are produced that measure tourism development. Table 1 shows the results of the study of tourism indicators according to Inskeep (Inskeep, 1991) and (Goeldner \& Ritchie, 2009).

Table 2: Result of Component and Tourism Study

\begin{tabular}{|l|l|l|}
\hline \multicolumn{1}{|c|}{ Indicator } & \multicolumn{1}{|c|}{ Inskeep (1991) } & \multicolumn{1}{|c|}{ Charles R.G and J. R Brent (2009) } \\
\hline Tourism Attraction & Attraction & $\begin{array}{l}\bullet \text { Natural resources } \\
\bullet \text { Local culture } \\
\bullet \text { Supporting attraction }\end{array}$ \\
\hline Infrastructure & $\begin{array}{l}\bullet \text { Accommodation } \\
\bullet \text { Services facilities }\end{array}$ & $\bullet$ Information technology \\
\hline Accessibility & Transportation & Transportation \\
\hline Participation of society & $\begin{array}{l}\text { Development Plan, Promotion, and } \\
\text { Organization }\end{array}$ \\
\hline Institution & $\begin{array}{l}\text { Institution of } \\
\text { Organization }\end{array}$ & \\
\hline
\end{tabular}

2) Direct Observation and Pre-survey

Observations and pre-surveys were used to determine the existing conditions of the current Selong Belanak village and the wishes of the community in the tourism village development program. There are three main points raised in the pre-survey, namely: tourism potential, main and supporting facilities, community wants and needs related to tourism development, constraints that may be faced and others.

3) Focus Group Discussion (FGD)

Focus Group Discussion to directly accommodate the aspirations of the Selong Belanak villagers regarding the tourism development program that will be implemented, the community's 
recommendations regarding the program to be developed, the problems that exist in the current village, the economic and cultural conditions of the village community.

\section{4) Compilation of List of Indicators}

Based on the results of the study of literature, observation, pre-survey and FGD, the indicators are translated into instruments (measuring instruments) that can be used to assess the condition of an area that is a coastal tourist destination, following a list of tourism indicators Selong Belanak Village.

Table 3: Result of Tourism Development Indicator Study Based on Selong Belanak Village Existing State

\begin{tabular}{|c|c|c|}
\hline No & Indicator & Variable \\
\hline 1 & Natural Resource & $\begin{array}{l}\text { - Existence of Natural Resourceon the coast, agriculture } \\
\text { resource, dan sea water ecosystem } \\
\text { - The state of coast and sea water ecosystem }\end{array}$ \\
\hline 2 & Infrastructure & $\begin{array}{l}\text { - Accommodation } \\
\text { - Tourism Facility } \\
\text { - Tourism Facility Layout } \\
\text { - Health Facility } \\
\text { - Tourism Supporting Facility }\end{array}$ \\
\hline 3 & Accessibility & $\begin{array}{l}\text { - Existence of Guiding Direction } \\
\text { - Existence of Transportation }\end{array}$ \\
\hline 4 & Culture & $\begin{array}{l}\text { - Culture uniqueness } \\
\text { - Culture Performs }\end{array}$ \\
\hline 5 & $\begin{array}{l}\text { Society Involvement } \\
\text { and employment }\end{array}$ & $\begin{array}{l}\text { - Society activities related to tourism actitvity } \\
\text { Society role in managing tourism objects (employment) }\end{array}$ \\
\hline 6 & Institution & Exsistence of institution managing tourism activity \\
\hline 7 & $\begin{array}{c}\text { Security and } \\
\text { Concvenience }\end{array}$ & Security and convenience guaranty for tourists \\
\hline 8 & Economy & $\begin{array}{l}\text { - Amount of business related to toourism sector } \\
\text { - Purchasing power of society }\end{array}$ \\
\hline 9 & Chance in ivestation & $\begin{array}{l}\text { - Investation support from government } \\
\text { - Foreign Investation }\end{array}$ \\
\hline 10 & $\begin{array}{l}\text { Policy of tourism } \\
\text { management }\end{array}$ & $\begin{array}{l}\text { - Existence of government policy related to tourism } \\
\text { - Stakeholder involvement in tourism management } \\
\text { - Involvement of private sector } \\
\text { - Tourism management policy }\end{array}$ \\
\hline 11 & Imaging and Promotion & $\begin{array}{l}\text { - Society in promoting tourism attraction } \\
\text { - Existence of party for cooperation in promoting tourism } \\
\text { spots } \\
\text { - Local culture attraction promoting plan }\end{array}$ \\
\hline
\end{tabular}


5) Conduct Surveys using Instruments that have been compiled

The purpose of the survey was to test instruments and produce data on existing conditions in coastal tourism destination areas

\section{Result And Analysis}

\subsection{Scores Indicator}

Based on the results of a survey of stakeholders that have been carried out, an assessment or scoring of indicators to measure the sustainability of de Selong Belanak maritime tourism is conducted. The results of the assessment of each indicator can be seen in the table 3

Table 3 shows the values for each indicator based on stakeholder assessments in the Selong Belanak Village. The stakeholders considered that Institutional indicators were the highest priority indicator to get improvements and follow-up to support tourism in the Selong Belanak Village because it had the lowest value of 0.425 , almost many respondents were uninformed about tourism management institutions. In addition, according to village stakeholders, tourism development indicators that must be prioritized first to be followed up are Society Involvement and promotion.

Table 4: Scoring Result of Tourism Development Indicator Based on Selong Belanak Village Existing State

\begin{tabular}{|c|l|c|}
\hline No & \multicolumn{1}{|c|}{ Indicator } & Score \\
\hline 1 & Natural Resource & 2.200 \\
\hline 2 & Infrastructure & 1.788 \\
\hline 3 & Accessibility & 1.661 \\
\hline 4 & Culture & 2.476 \\
\hline 5 & Society involvement and Employment & 1.513 \\
\hline 6 & Institution & 0.425 \\
\hline 7 & Security and Convenience & 2.214 \\
\hline 8 & Socio-Economy & 2.034 \\
\hline 9 & Chance in Investation & 1.595 \\
\hline 10 & Tourism Management Policy & 2.068 \\
\hline 11 & Branding and Promotion & 1.054 \\
\hline
\end{tabular}

Whereas the indicator of Culture has the highest score of 2.476, stakeholders consider that the existing culture is quite varied and unique, but requires some improvement and follow-up such as the introduction of cultural attractions to attract the attention of tourists to come to the village 
of Selong Belanak. The following are the results of assessments for each indicator of tourism development based on Community Based Tourism.

\subsubsection{Indicators of Natural Resources}

Stakeholders assess that the condition of coastal and marine ecosystems has good potential for tourism development but the community has not given high priority to natural resource management, protection of coastal and marine ecosystems, processing of marine resources and tourism supporting resources because most people do not know information about special protection for the coastal and marine ecosystems. On the other hand, it is necessary to follow up on the results of processing the results of resources and processing of natural resources as a tourism area.

\subsubsection{Indicators of Facilities and Infrastructure}

Most of the respondents agree that accommodation facilities such as homestays and hotels have met the standards to serve the needs of overnight travelers, in addition tourist facilities such as restaurants or surf equipment rentals have sufficiently met existing tourism standards.

\section{a. Accommodation Facilities}

According to the community, the condition of accommodation facilities for tourists such as hotels and resorts owned by outside or private parties is considered to be sufficient, while for homestays and guesthouses belonging to the local community have not met the standards and are far from feasible. Therefore the community considers that there needs to be improvement, input and advice in the field of accommodation

\section{b. Tourism Facilities}

Most people agree that the existence of tourism facilities such as: ATM centers, banks, information centers, and gas stations is so lacking that it needs to be prioritized. At present there are only one unit of facilities in the village of Selong Belanak, namely ATMs and these facilities are located in certain hotel areas, so that people cannot be free to use them. Therefore, if people want to do a transaction, they have to go to Praya city, which takes about an hour from Selong Belanak Village.

\section{c. Health Facility}

The existence of health facilities for tourists and the community is a top priority in the village of Selong Belanak at present, there are only two health facilities in the village of Selong Belanak, namely the Village Health Center and Auxiliary Health Center. there were severe 
accidents or serious illnesses to tourists or the public, so they would take them to Harapan Keluarga Hospital in the city of Mataram, which took about one hour from Selong Belanak Village.

\section{d. Tourism Spatial Planning}

According to the village stakeholders, the condition of the spatial layout of the tourism area is currently considered to be very inadequate, so the area still looks less comfortable for tourists and the community. According to them, the matters that need to be managed in spatial planning are beachside restaurants, drainage, and waste management, because at this time, the existing spatial layout is considered to be unfavorable and still slum. In addition to these three things, the community also prioritizes spatial planning for fishing villages that are located along the coast of Selong Belanak. The existence of a fishing village is considered by the community to be quite disturbing to the view of the coast, because of its slum and dense condition. In 2017 there is a Kampung Nelayan relocation program, to clarify the location of fisheries and tourism, but to date, the program has not run.

\section{e. Environmental Management}

Village stakeholders, community awareness of environmental cleanliness is still lacking. Waste management in Selong Belanak Village is still not sufficiently adequate and organized. However, in early October 2018, the community received assistance from one of the foreignowned resorts, in the management of waste, so that according to village stakeholders, the condition of the community had begun to be aware of environmental cleanliness.

\section{Indicators of Accessibility}

Accessibility is the availability of facilities that make visitors have the convenience to reach tourism destinations. The existence of the Selong Belanak village which is relatively close to the Praya Lombok international airport makes Selong Belanak Beach easy to reach by tourists. The access road to the Selong Belanak beach is quite good, but the road conditions are not yet sufficient because there are still many damaged roads. The means of transportation to the tourist area can only be used by car (travel) from the airport to the village of Selong Belanak because public transportation is not yet available. The condition of the trail used by tourists to enjoy the natural beauty around the tourist area is still not good, the lighting is still lacking and poor drainage and the absence of sidewalks.

Apart from transportation, the condition of the main (national) road is quite good. Access roads that connect tourist sites like from Kuta Beach to Selong Belanak Village are quite good, 
although according to the community the road is still not wide enough. The road to Selong Belanak beach is not yet equipped with adequate road signs.

\subsubsection{Indicator of Culture}

Selong Belanak village has a unique culture that can be used as a tourist attraction, including Nyongkolan culture (applying for a girl to marry), Gendang Belik (an instrument used to accompany sacred events such as weddings), Nyale (looking for worms at sea) held every two years once on the 19th of the 10th month of the Sasak and Nyonelokan, Wayang Kulit, Ciloka (dance performances), and Tarung Rotan. According to stakeholders, at this time the uniqueness of the culture has not been fully utilized to attract tourists' attention.

\subsubsection{Indicators of Society Involvement and Employment}

The participation of local people in tourism management of new members of the community is limited to being a worker and a small number become owners of tourist facilities such as restaurant and homestay owners. Most tourism management is carried out by local governments and private parties. One program of community participation in coastal management is maintaining the cleanliness of the beach through the Beach Boy, however the results of the survey and FGD stated that the people of the Selong Belanak village strongly supported the development of tourism. The community is aware of the importance of a good environment to increase visitors and is willing to protect the village environment to be safe and comfortable for tourists when visiting. In addition, to support the development of tourism in the Selong Belanak Village, according to stakeholders, the community is still lacking and requires self-development training and skills, both regarding language and work skills.

\subsubsection{Socio-Economic Indicators}

The economic activities of people in the Selong Belanak region are generally agriculture and fisheries. Economic activities related to tourism, for example stall business, lodging, transportation services, rental by beach sports equipment, tour guides, and travel agents. But there is no analysis of how much the economic contribution in the field of tourism in the village of Selong Belanak. Tourist data related to profiles and tourist activities are also available.

The survey results on public awareness indicate that the tourism sector is a leading sector that is quite high in demand. Most people assume that the tourism sector is a sector that is able to sustain the lives of local people, so that people are expected to be more prosperous and the level of purchasing power of local people to increase. 


\subsubsection{Institutional Indicators}

The existence of institutions in the village of Selong Belanak related to tourism management is still lacking. Even the public is not aware of the existence of institutions that manage tourism activities, trade activities related to the tourism sector, and institutions that participate in managing tourist accommodation, institutions that are responsible for the cleanliness of the tourist environment. Therefore, people with their own awareness maintain cleanliness according to the knowledge and standards they have. The community also does not know about the existence of supporting institutions such as institutions that can provide skills training in managing stalls, lodging, environmental hygiene and others.

Stakeholders stated that the existence of these institutions was a very high priority to be immediately followed up by the village government and regional government, because the community is aware that these institutions are very important in the process of tourism development (having the highest priority scale). However, in the village of Selong Belanak there is already a Vocational Middle School in Tourism.

\subsubsection{Indicators of Security and Comfort}

Safety and comfort in the village of Selong Belanak is considered quite good by most respondents. This security and convenience is obtained because public awareness that plays an active role in protecting tourists who come if tourists experience difficulties such as experiencing loss of public goods will be very helpful. Visitors' comfort is also supported by public awareness not to disturb visitors with hawkers. Unfortunately, the government still lacks support because there is no special institution that plays a role and is responsible for maintaining the security and comfort of tourists. The presence of security guards and tourist safety on the beach was classified as lacking due to a lack of personnel and difficulty reaching each of the vulnerable points on the beach. At present, the institutions that take an active role in maintaining security in the Selong Belanak Village are the Police, Satpol PP, and Security, while the institutions that maintain the welfare of tourists while visiting the Beach consist of the Coastal Safety Unit and the Marine Security.

\subsubsection{Branding and Promotion Indicators}

The imaging and promotion of the Selong Belanak Tourism Area is very important to do in order to increase tourist visits to Selong Belanak. Imaging and promotion have not been done in a structured manner, the community, especially tourists themselves, do it through social media. There is no clear plan regarding the steps that must be taken for imaging and promotion, therefore 
the respondent did not provide information on the indicators of the existence of the design introducing the beauty of the Selong Belanak beach and various tourist supporting attractions.

\subsubsection{Indicators of Investment Opportunities}

Selong Belanak tourist location that has stunning natural scenery attracts investors. At present there are a number of hotels that are well closed in the region and there have been investors who want to develop an Isatta business in the region by buying land that is widely sansat. Selong Belanak has good potential for investment entrepreneurs. However, when the investment activity was carried out in this area it was not transparent. The community does not know how to plan the development of Selong Belanak in the future. Development in the village of Selong Belanak is quite slow.

\subsubsection{Indicators of Tourism Management Policy}

Tourism management policies are urgently needed to provide direction for tourism development so that all stakeholders, especially the community, can play an active role in the development of tourism. So far there has been no specific policy regarding the development of tourism in the Selong Belanak Village. The existence of the Selong Belanak tourism development plan is a matter that is highly prioritized by village stakeholders and the village government. Policies are needed that can regulate the development and maintenance of tourism in Selong Belanak so that tourism sustainability can be guaranteed and provide welfare for local communities.

The involvement of the private sector in developing and managing tourism activities in the village of Selong Belanak still looks lacking. The private sector still lacks a role in improving the quality of the environment around the coast and the government also does not involve the private sector to jointly build tourism in the village of Selong Belanak.

Likewise, the involvement of other stakeholders, both the central government, regional government and village government and other community institutions, especially to develop the capabilities and skills of the community, conduct environmental arrangements, improve security and others. Activities to invite stakeholders or stakeholders to get involved in tourism governance are also a maximum.

\subsection{Program Strategy and Priority}

The design of tourism development strategies in Selong Belanak Village is a further stage after the identification process regarding indicators of tourism development to determine several 
alternative priority strategies. Based on the results of the study analysis of indicators of tourism development, the formulation of the priority strategy design was made as follows

\subsubsection{Clarify Accessibility and Build Tourism Infrastructure}

The things that need to be recommended to the local government to facilitate accessibility to the Selong Belanak tourist site are to build the main gates and road directions, repair national roads from Lombok International Airport to the tourist area, while to support tourism activities for visitors, it is necessary to develop Eco -Tourism Center and adequate health facilities.

\subsubsection{Establishment of Institutions that Support Tourism Activities and Arrangement of Regional Spatial Planning}

The existence of institutions that manage tourism activities is very important, because these institutions will accommodate tourism actors to build aspirations to develop tourism activities. The institutions that need to be established to support tourism activities are institutions that regulate trade activities in the tourism sector; institutions that accommodate owners of accommodation facilities, and institutions that regulate environmental cleanliness.

\subsubsection{Improving the Quality of Human Resources in Managing Tourism}

In tourism management, the availability of human resources is very important because it involves service. HR involved in tourism activities must be built first through training or recruitment of experienced and educated human resources to manage tourism in the Selong Belanak Village. Activities that can be carried out to realize this program are as follows:

i. Training and coaching for restaurant owners and employees

ii. Training and coaching for hotel owners and employees and travel agents

iii. Educational programs and scholarships for tourism homestay

\subsubsection{Developing Command, Private and Community Cooperation for Investment Opportunities}

Tourism development is a task for all elements, both from the community, private parties, and the local government itself. In this case, the government is expected to be able to provide guidance and information about the meaning of development in the tourism sector so that it will increase public awareness and concern for its potential, provide guidance and training to the community to make regional handicrafts and souvenirs in the hope of reducing unemployment, providing working capital assistance and expanding tourism marketing in Selong Belanak Village. While the role for the private sector and the community is directed at the fields of business and tourism support activities such as travel agent business, accommodation, consumption, cultural 
attractions, and services to tourists. To implement this strategy, the government created a program that could provide knowledge and awareness for the private sector and the community for develop tourism, safeguard the marine environment such as conserving coral reefs, rehabilitating damaged coral reefs, and making regional regulations and regulations on the preservation of marine tourism sites prioritized nature tourism.

\subsubsection{Plan Tourism Imaging and Promotion Activities}

Promotional activities are important in tourism development. The ease of access to technology and information now facilitates these two activities, such as promotion through social media, the community can help activities and promotions easily and quickly. In addition, with this technology, the community is also facilitated in expanding promotional activities to international level. As for imaging activities, identity needs such as logos and tourist attractions are needed

\section{Conclusions and Suggestions}

\subsection{Conclusion}

Village stakeholders, assessing that there are several indicators of tourism development that need to be prioritized to be followed up, namely accessibility, facilities and infrastructure, institutions that support tourism activities, community participation especially labor skills, as well as imaging and promotion. As for some indicators, such as Culture and Social Economy, stakeholders assessed that these indicators were quite good, but needed some improvement and follow-up.

\subsection{Suggestions}

Tourism development requires the support of every element such as the community, the private sector and the regional government, so that planned or prioritized strategies can run smoothly. In addition, there needs to be awareness from the community itself about the tourism environment, so that tourists who visit can feel safe and comfortable.

\section{Reference}

Goeldner, C. R., \& Ritchie, B. J. (2009). Tourism Principles, Practices, Philosophies. Hoboken, New Jersey: Jonh Wiley \& Sons, Inc.

Helmer, O. (1967). Analysis of the Future : The Delphi Method. California: Rand Corp Santa Monica CA.

Inskeep, E. (1991). Tourism Planning: An Integrated Sustainable Development. 
Kementrian, P. (2016). Laporan Akuntabilitras Kinerja Kementrian Pariwisata . Jakarta: Biro Perencanaan dan Keuangan, Sekretariat Kementrian.

Linstone, H. A., \& Turrof, M. (2002). The Delphi Method : Techniques and Application.

Miller, G. (2001). The Development of Indicators for Sustainable Tourism: Result of a Delphi Survey of Tourism Researchers. Tourism Management 22, 351-362. https://doi.org/10.1016/S0261-5177(00)00067-4

Moldan, B. (1997). Desicion Makaing Cycle. In B. Moldan, \& S. Bilharz (Eds.), Sustainability indicators: Report of The Project on Indikators of Sustainable Development (pp. 1-5). Chichester: Wiley \& Sons.

Putra, H. P. (2017). Analisis Potensi Pengembangan Pariwisata Di Kabupaten Lombok Tengah Provinsi Nusa Tenggara Barat. Surakarta.

Walpole, R. E. (1993). Pengantar Metode Statistika. Jakarta: PT Gramedia Pustaka Utama.

World Tourism Organization (UNWTO). (2013). Sustainable Tourism for Development Guidebook. Capitán Haya, 42 - 28020 - Madrid (Spain): Institutional and Corporate Relations Programme. 